\title{
Primary squamous cell carcinoma of the pancreas with a large pseudocyst of the pancreas as the first manifestation: a rare case report and literature review
}

Xia Qiu ${ }^{1 \dagger}$, Yajie Meng ${ }^{1 \dagger}$, Meiqin Lu ${ }^{1 \dagger}$, Chuan Tian ${ }^{1}$, Min Wang ${ }^{1}$ and Junwen Zhang ${ }^{2^{*}}$ (1)

\begin{abstract}
Background: Primary squamous cell carcinoma (SCC) of the pancreas with pseudocysts, especially diagnosed by endoscopic ultrasound-guided fine-needle aspiration (EUS-FNA), is extremely rare.

Case presentation: A 64-year-old man was admitted to our department for abdominal distension. Two months ago, he experienced abdominal pain for 1 day and was diagnosed with acute pancreatitis in another hospital. After admission, laboratory tests showed the following: amylase $400 \mathrm{U} / \mathrm{L}$, lipase $403 \mathrm{U} / \mathrm{L}$, and carbohydrate antigen 19-9 (CA19-9) $347 \mathrm{U} / \mathrm{mL}$. Abdominal computed tomography $(\mathrm{CT}$ ) revealed pancreatitis with a pseudocyst with a diameter measuring $7 \mathrm{~cm}$. During linear EUS, a large pseudocyst $(5.4 \times 5.2 \mathrm{~cm})$ was observed in the pancreatic body. EUS-FNA was performed. We obtained specimens for histopathology and placed a plastic stent through the pancreas and stomach to drain the pseudocyst. Puncture fluid examination revealed the following: CA19-9>12,000 U/mL carcinoembryonic antigen (CEA) $7097.42 \mathrm{ng} / \mathrm{ml}$, amylase 27,145.3 U/L, and lipase > $6000 \mathrm{U} / \mathrm{L}$. Cytopathology revealed an abnormal cell mass, and cancer was suspected. Furthermore, with the result of immunohistochemistry on cell mass (CK (+), P40 (+), p63 (+), CK7 (-) and Ki-67 (30\%)), the patient was examined as squamous cell carcinoma (SCC). However, the patient refused surgery, radiotherapy and chemotherapy. After drainage, the cyst shrank, but the patient died 3 months after diagnosis due to liver metastasis and multiple organ failure.
\end{abstract}

Conclusion: For patients with primary pancreatic pseudocysts with elevated serum CEA and CA19-9 levels, we should not rule out pancreatic cancer, which may also be a manifestation of primary pancreatic SCC. EUS-FNA is helpful for obtaining histopathology and cytology and thus improving diagnostic accuracy.

Keywords: Squamous cell carcinoma, Pancreas, Pseudocyst, Endoscopic ultrasound-guided fine-needle aspiration

\section{Background}

Pancreatic squamous cell carcinoma (SCC) is a primary rare malignancy, accounting for $0.5-2.0 \%$ of all malignant pancreatic tumors, and is considered an aggressive

\footnotetext{
*Correspondence: zhangjw1207@163.com

${ }^{\dagger}$ Xia Qiu, Yajie Meng and Meiqin Lu contributed equally to this work

${ }^{2}$ Department of Gastroenterology, The First Affiliated Hospital

of Chongqing Medical University, Chongqing 400016, China

Full list of author information is available at the end of the article
}

subtype with a poor prognosis $[1,2]$. In recent years, an increasing number of pancreatic lesions have been diagnosed by endoscopic ultrasound-guided fine-needle aspiration or biopsy (EUS-FNA or EUS-FNB) [3-7]. However, nearly all of the cases were solid or solid-cystic lesions of the pancreas. To our knowledge, there have been no cases of primary SCC of the pancreas with pseudocysts, especially those diagnosed by EUS-FNA. Here, we report a rare case of SCC of the pancreas with a pseudocyst as the main presentation. 


\section{Case presentation}

A 64-year-old man was admitted to our department for abdominal distension. Two months ago, he experienced abdominal pain for 1 day and was diagnosed with acute pancreatitis in another hospital. There was no cystic lesion of pancreas at that time. The patient did not present with cutaneous or sclera icterus, fever, melena, swallowing difficulties or diarrhea but did present with weight loss of $2 \mathrm{~kg}$. After admission, the physical examination showed that the patient had tenderness in the upper abdomen, and a mass approximately $5.0 \times 6.0 \mathrm{~cm}$ in size and soft in texture could be felt in the upper abdomen. The results of other physical examinations were unremarkable. He denied alcohol use or any history of chronic or significant medical or family illnesses. After admission, laboratory tests showed the following: amylase 400 U/L (normal, 0-40 U/L), lipase $403 \mathrm{U} / \mathrm{L}$ (normal, 0-60 $\mathrm{U} / \mathrm{L}$ ), carbohydrate antigen 19-9 (CA19-9) $347 \mathrm{U} / \mathrm{mL}$ (normal, $<39 \mathrm{U} / \mathrm{mL}$ ), and albumin $31.4 \mathrm{~g} / \mathrm{L}$. Other routine laboratory tests did not indicate any abnormalities.

Contrast-enhanced abdominal computed tomography (CT) revealed pancreatitis with a pseudocyst (diameter $7 \mathrm{~cm}$ ), in which there was fluid (Fig. 1). In the cyst, no necrotic tissue was found and the boundary was clear. Additionally, no obvious low-density mass was found around the cyst and the tail of pancreas was atrophied. The diameter of the pancreatic duct was approximately $0.45 \mathrm{~cm}$. There were no enlarged lymph nodes in the upper abdomen. In addition, the CT scan of the chest was normal. MRCP revealed that there was no debris in

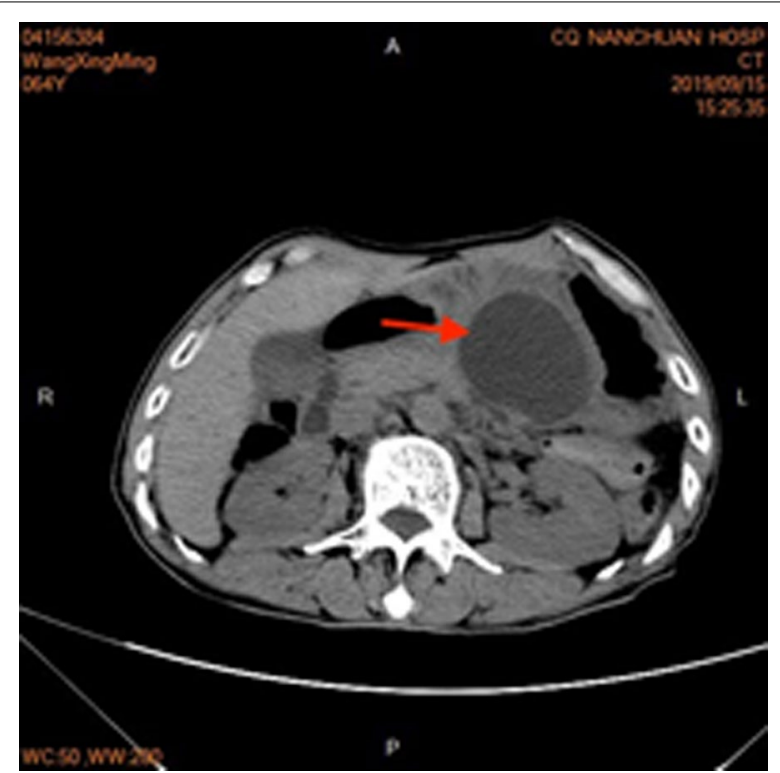

Fig. 1 Abdominal CT revealed pancreatitis with a pseudocyst (red arrow) with a diameter measuring $7 \mathrm{~cm}$ the cyst, the pancreatic duct in the head of pancreas was not dilated, and the main pancreatic duct was not connected with the cyst.

Gastric endoscopy showed no abnormal findings in the upper gastrointestinal tract. During the linear EUS examination, a large pseudocyst was observed in the body of the pancreas with a maximum US cross-section of approximately $5.4 \times 5.2 \mathrm{~cm}$. The margin of the cyst was clear and no blood flow was detected with color Doppler ultrasonography. Some hyperechoic floccules were observed in the cyst and there was septum in the lumen. There was no debris in the cyst, and the cyst fluid aspirated by EUS-FNA was also without debris. There was no obvious dilatation of the pancreatic duct. Endoscopic ultrasound-guided fine-needle aspiration (EUSFNA) was performed. The exact site of EUS-FNA was the posterior wall of the upper part of the stomach, and the distance between the ultrasonic probe and the cyst was no more than $1 \mathrm{~cm}$. After puncturing the cystic lesion, the stylet was removed, and $10 \mathrm{~mL}$ of negative pressure suction was applied within the lesion. The syringe was filled with brown liquid. We collected $20 \mathrm{ml}$ of fluid for the examination of amylase, carcinoembryonic antigen (CEA), and CA19-9. We also performed EUS-FNA to obtain specimens for histopathology and placed a plastic stent for drainage of the pseudocyst through the pancreas and stomach (Fig. 2). Puncture fluid examination revealed the following: CA19-9 > 12,000 U/ml, CEA $7097.42 \mathrm{ng} / \mathrm{ml}$, amylase 27,145.3 U/L, and lipase $>6000$ $\mathrm{U} / \mathrm{L}$.

After EUS-FNA, pathological cytology revealed an atypical cell mass, and cancer was suspected. Based on the immunohistochemistry results, CK $(+), \mathrm{P} 40(+)$, p 63 $(+)$, CK7 (-) and Ki-67 (30\%), the patient was diagnosed as squamous cell carcinoma (SCC) (Fig. 3).

The patient refused surgery, radiotherapy and chemotherapy. After drainage, the cyst shrank, but the patient died 3 months after diagnosis, due to liver metastasis and multiple organ failure.

\section{Summary of previously reported cases from 2009 to 2020}

We searched PubMed for the following keywords in the title/ abstract and found 15 cases of SCC of the pancreas reported from 2009 to 2020: "squamous cell carcinoma", "pancreas", "endoscopic ultrasound-guided fine-needle aspiration" and "EUS-FNA" [8-23]. A summary of these cases is displayed (Table 1). The patients ranged in age from 45 to 82 years, with a mean age of $67.9 \pm 6.7$ years. Among these 15 patients, only one had cystic lesions, which was diagnosed by EUS-guided confocal endoscopy, 1 had cystic and solid lesions, and the others had solid masses of the pancreas. There were no reports on pseudocyst-associated pancreatic SCC. Among 


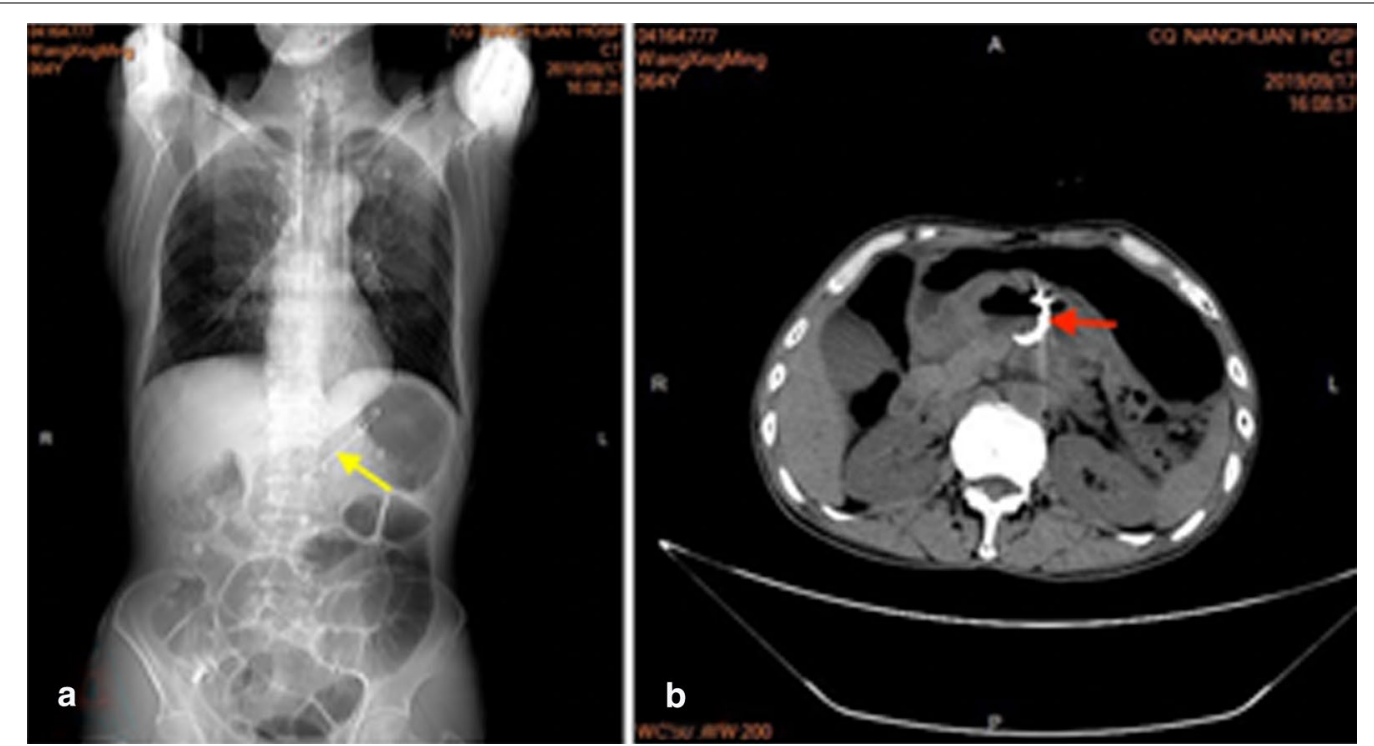

Fig. 2 A plastic stent was placed for drainage of the pseudocyst through the pancreas and stomach. a The double pigtail plastic stent (yellow arrow) under X-ray. $\mathbf{b}$ One tail of the stent (red arrow) is located in the pseudocyst
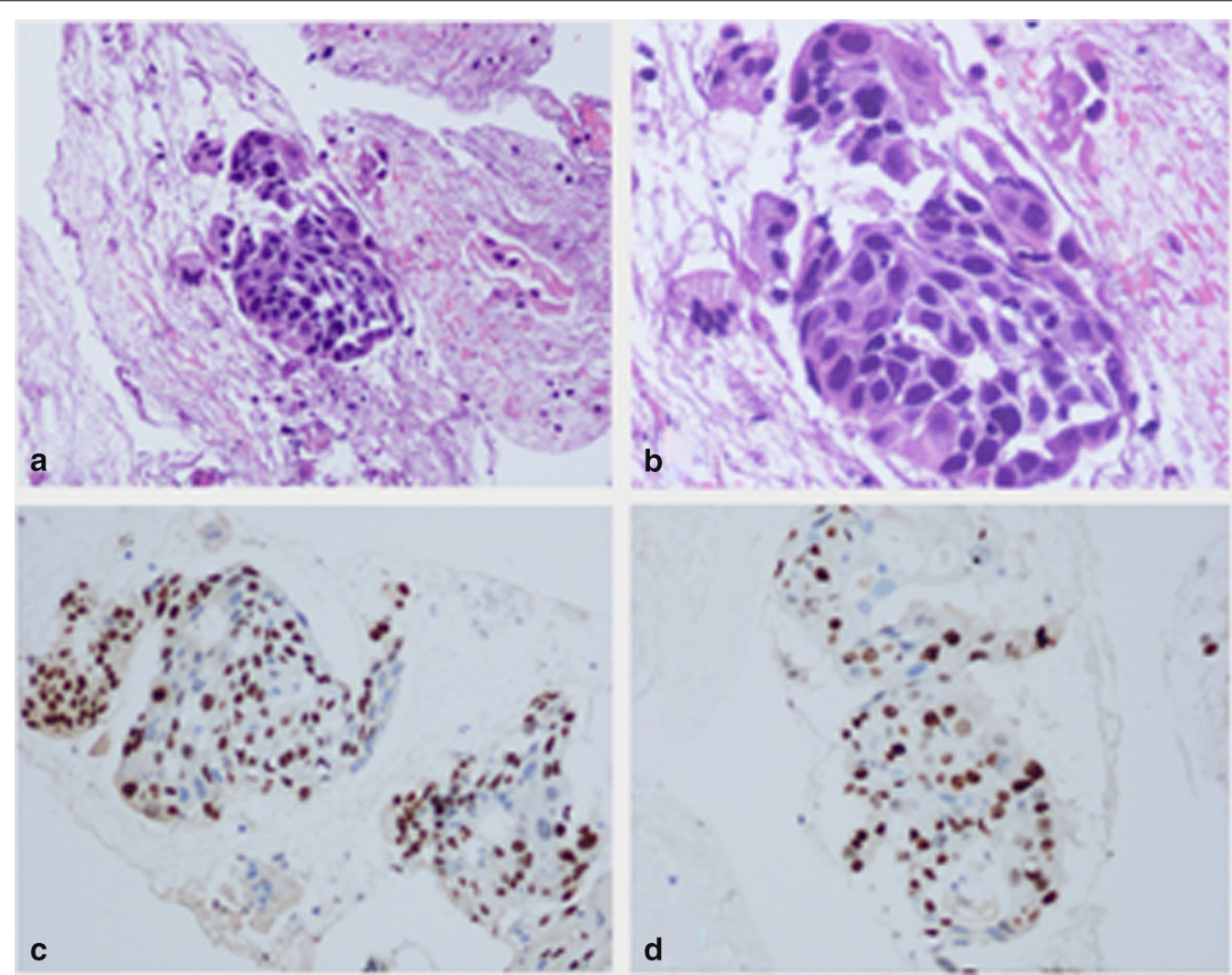

Fig. 3 Based on histopathology combined with immunohistochemistry, the patient was diagnosed with squamous cell carcinoma (a HE $\times 100, \mathbf{b}$ HE $\times 200)$. Immunohistochemical analysis showed the following: P40 (+) (c) and Ki-67 (30\%) (d) 
Table 1 Clinical features of 15 cases with pancreatic squamous cell carcinoma diagnosed by EUS-FNA

\begin{tabular}{|c|c|c|c|c|c|c|}
\hline \multirow[t]{2}{*}{ Year } & \multirow[t]{2}{*}{ First author } & \multicolumn{2}{|l|}{ Diagnostic mode } & \multirow[t]{2}{*}{ Metastasis } & \multirow[t]{2}{*}{ Therapy } & \multirow[t]{2}{*}{ Surviva*(months) } \\
\hline & & $\mathrm{CT}$ & EUS and pathology & & & \\
\hline 2009[8] & Larry Hin Lai & $\begin{array}{l}\text { Partial cystic mass } \\
\text { in the tail of the } \\
\text { pancreas }\end{array}$ & FNA/Cytopathology & Liver & - & - \\
\hline 2009[9] & Santiago Sotolglesias & Pancreatic mass & FNA/Cytopathology & None & $\begin{array}{l}\text { Chemotherapy/radia- } \\
\text { tion }\end{array}$ & 12 \\
\hline 2013[10] & Sepideh Nikfam & $\begin{array}{l}\text { Solid mass of pancre- } \\
\text { atic body / tail }\end{array}$ & $\begin{array}{l}\text { FNA/Cytopathology/ } \\
\text { Immunopathology }\end{array}$ & $\begin{array}{l}\text { Liver and carina of the } \\
\text { trachea }\end{array}$ & Chemotherapy & 9 \\
\hline 2014[11] & Alan Brijbassie & $\begin{array}{l}\text { Cystic lesions of } \\
\text { uncinate process of } \\
\text { pancreas }\end{array}$ & FNA/Cytopathology & $\begin{array}{l}\text { Adjacent lympho- } \\
\text { nodus }\end{array}$ & Radiation & - \\
\hline 2015[12] & Mudresh Mehta1 & Pancreatic tail mass & $\begin{array}{l}\text { FNA/Cytopathology/ } \\
\text { Immunopathology }\end{array}$ & None & - & 2 \\
\hline 2016[13] & Kyle Rowe & $\begin{array}{l}\text { Pancreatic head mass, } \\
\text { secondary cystic } \\
\text { dilatation of pancre- } \\
\text { atic tail }\end{array}$ & FNA/Cytopathology & Liver & - & - \\
\hline 2017[14] & Rohan M.Modi & $\begin{array}{l}\text { Cystic disease of } \\
\text { pancreas }\end{array}$ & $\begin{array}{l}\text { EUS-guided needle- } \\
\text { based confocal laser } \\
\text { endomicroscopy } \\
\text { (nCLE) with an AQ- } \\
\text { Flex } 19 \text { miniprobe/ } \\
\text { Cytopathology }\end{array}$ & Liver & - & - \\
\hline 2017[15] & $\begin{array}{l}\text { Fernando Martínez } \\
\text { de Juan }\end{array}$ & $\begin{array}{l}\text { Solid and cystic mass } \\
\text { of pancreas }\end{array}$ & $\begin{array}{l}\text { FNA/Cytopathol- } \\
\text { ogy and Partial } \\
\text { pancreatectomy: } \\
\text { Cytopathology/ } \\
\text { Immunopathology }\end{array}$ & $\begin{array}{l}\text { Adjacent lympho- } \\
\text { nodusl }\end{array}$ & Surgery & $>5$ \\
\hline 2017[16] & Amir Kashani & Pancreatic tail mass & $\begin{array}{l}\text { EUS-CNB/Cytopathol- } \\
\text { ogy//Immunopa- } \\
\text { thology }\end{array}$ & Liver & - & - \\
\hline 2017[17] & Bader A Alajlan & Pancreatic tail mass & FNA/Cytopathology & None & - & 3 \\
\hline 2017[18] & Ryan Glass & $\begin{array}{l}\text { Cystic mass of head of } \\
\text { pancreas }\end{array}$ & $\begin{array}{l}\text { FNA/Cytopathology/ } \\
\text { Immunopathology }\end{array}$ & - & Chemotherapy & $>4$ \\
\hline 2017[19] & Seyed Hassan Abedi & $\begin{array}{l}\text { Mass of body and tail } \\
\text { of pancreas }\end{array}$ & $\begin{array}{l}\text { EUS-FNA/Cytopathol- } \\
\text { ogy/Immunopa- } \\
\text { thology }\end{array}$ & - & - & 8 \\
\hline 2017[20] & $\begin{array}{l}\text { Diogo Turiani } \\
\text { Hourneaux De } \\
\text { Moura }\end{array}$ & $\begin{array}{l}\text { Solid mass of head of } \\
\text { pancreas }\end{array}$ & $\begin{array}{l}\text { EUS-FNA/Cytopathol- } \\
\text { ogy }\end{array}$ & - & $\begin{array}{l}\text { ERCP and entirely } \\
\text { covered metallic } \\
\text { stent }\end{array}$ & 1 \\
\hline 2018[21] & Ge Zhang & Pancreatic mass & $\begin{array}{l}\text { EUS-FNA/Cytopathol- } \\
\text { ogy }\end{array}$ & Gastric wall and Liver & Radiation & 8 \\
\hline 2019[22] & Nikolaos Machairas & Pancreatic head mass & $\begin{array}{l}\text { EUS-FNA/Cytopathol- } \\
\text { ogy }\end{array}$ & None & Surgery & 2 \\
\hline
\end{tabular}

the 15 patients, more than $50 \%(8 / 15)$ had metastasis at diagnosis. Although the patients received different treatments, including surgery, radiotherapy and chemotherapy, the survival time of almost all patients was less than 12 months. The prognosis of pancreatic SCC is poor.

\section{Discussion and conclusions}

SCC is a very rare exocrine pancreatic malignant tumor. The clinical presentation of primary SCC of the pancreas is similar to that of ductal adenocarcinoma of the pancreas [24]. In 2019, Tella SH et al. searched the National Cancer Database (NCDB) (2004-15) and reported 182,090 patients prior to matching, 181,575 with pancreatic adenocarcinoma and 515 with SCC; thus, SCC accounted for only $0.28 \%$ of all pancreatic cancers. The proportions of patients with stage III and IV disease at diagnosis were $14 \%$ and $62 \%$, respectively. For stage IV disease, the most common distant sites of metastases were the liver (32\%) and lungs (6\%) [25]. Although different therapeutic methods have been used to treat 
pancreatic SCC, including surgical resection, chemotherapeutic regimens, and radiotherapy, none have proven effective [26]. The proportion of patients with stage III and IV disease at diagnosis was above $76 \%$, so survival was poor $[25,26]$.

EUS-FNA has been increasingly used for the identification of solid pancreatic lesions and has shown high sensitivity and specificity $[5,6]$. EUS-FNA is also helpful for obtaining histopathology and cytology results to improve diagnostic accuracy in pancreatic cystic neoplasms. A combined analysis of cyst fluid CEA, CA19-9, and cyst fluid lipase levels provides the highest accuracy for differentiating malignant and benign pancreatic cystic lesionsn [27]. Pancreatic malignant cysts usually have the following characteristics: they are found in middle-aged and elderly people without a history of pancreatitis; imaging is often accompanied by separation, calcification, and pancreatic duct expansion; the contents of the cysts are mostly mucus, nipple, and solid components; and the level of amylase in the cysts is low [28]. However, in our case, there was no obvious sign of a malignant cyst at the initial examination. The patient experienced abdominal pain and was diagnosed with acute pancreatitis, which ultimately resulted in a large pseudocyst. During EUSguided drainage, the color of the cyst fluid was brown, consistent with the appearance of a pseudocyst. Due to the increase in CA19-9, we performed EUS-FNA, but the final diagnosis was SCC of the pancreas. Disease progression was also consistent with that of pancreatic SCC.

Normally, the pancreas lacks squamous epithelium. Although there are many hypotheses, the pathogenesis of pure SCC of the pancreas remains elusive [24]. However, for patients with pancreatic pseudocysts with elevated serum CEA and CA19-9 levels, we should not rule out pancreatic cancer, which may also be a manifestation of primary pancreatic SCC. Additional molecular biological studies are needed to confirm these findings.

\section{Abbreviations \\ SCC: Squamous cell carcinoma; EUS-FNA: Endoscopic ultrasound-guided fine-needle aspiration; CA19-9: Carbohydrate antigen 19-9; CEA: Carcinoem- bryonic antigen; CT: Computed tomography.}

\section{Acknowledgements}

We would like to express special gratitude to Professor Qiang Ma for kindly providing pathology knowledge and experience.

\section{Authors' contributions}

X.Q., K.Y.M. and J.Z. diagnosed the patient and prepared the manuscript; X.Q. and M.L. prepared the manuscript; and C.T. and M.W. designed and proofread the manuscript. All authors reviewed the final version of the manuscript. The author(s) read and approved the final manuscript.

\section{Funding}

None.

\section{Availability of data and materials}

This case report contains clinical data from the electronic medical record in The People's Hospital of Nanchuan, Chongqing, China. Additional information is available from the corresponding author on reasonable request from the editor.

\section{Declarations}

Ethics approval and consent to participate

Not applicable.

\section{Consent for publication}

Written informed consent was obtained from the patient's son for publication of this case report and any accompanying images. A copy of the written consent is available for review by the Editor-in-Chief of this journal.

\section{Competing interests}

The authors declare that they have no competing interests.

\section{Author details}

${ }^{1}$ Department of Gastroenterology, The People's Hospital of Nanchuan, Nanchuan District, No. 16 South Street, Chongqing 408400, China. ${ }^{2}$ Department of Gastroenterology, The First Affiliated Hospital of Chongqing Medical University, Chongqing 400016, China.

Received: 27 November 2020 Accepted: 3 May 2021

Published online: 08 May 2021

\section{References}

1. Brown HA, Dotto J, Robert M, Salem RR. Squamous cell carcinoma of the pancreas. J Clin Gastroenterol. 2005;39(10):915-9.

2. Makarova-Rusher OV, Ulahannan S, Greten TF, Duffy A. Pancreatic squamous cell carcinoma: a population-based study of epidemiology clinicopathologic characteristics and outcomes. Pancreas. 2016;45(10):1432-7.

3. Attiyeh MA, Chakraborty J, Doussot A, Langdon-Embry L, Mainarich S, Gonen M, Balachandran VP, D’Angelica MI, DeMatteo RP, Jarnagin WR, et al. Survival prediction in pancreatic ductal adenocarcinoma by quantitative computed tomography image analysis. Ann Surg Oncol. 2018;25(4):1034-42.

4. Tadic M, Stoos-Veic T, Kujundzic M, Turcic P, Aralica G, Boskoski I. Insulin-like growth factor 2 binding protein 3 expression on endoscopic ultrasound guided fine needle aspiration specimens in pancreatic ductal adenocarcinoma. Eur J Gastroenterol Hepatol. 2020;32(4):496-500.

5. Chen J, Yang R, Lu Y, Xia Y, Zhou H. Diagnostic accuracy of endoscopic ultrasound-guided fine-needle aspiration for solid pancreatic lesion: a systematic review. J Cancer Res Clin Oncol. 2012;138(9):1433-41.

6. Yoshinaga S, Suzuki H, Oda I, Saito Y. Role of endoscopic ultrasoundguided fine needle aspiration (EUS-FNA) for diagnosis of solid pancreatic masses. Digest Endosc. 2011;23(Suppl 1):29-33.

7. Oppong KW, Bekkali NLH, Leeds JS, Johnson SJ, Nayar MK, Darne A, Egan $M$, Bassett P, Haugk B. Fork-tip needle biopsy versus fine-needle aspiration in endoscopic ultrasound-guided sampling of solid pancreatic masses: a randomized crossover study. Endoscopy. 2020;52(6):454-61.

8. Lai LH, Romagnuolo J, Adams D, Yang J. Primary squamous cell carcinoma of pancreas diagnosed by EUS-FNA: a case report. World J Gastroenterol. 2009;15(34):4343-5.

9. Soto Iglesias S, Baltar Arias R, Vazquez Rodriguez S, Alvarez M, Gomez Martinez P, Alvarez Sanchez MV, Vazquez Astray E. Virchow's node as the form of onset of squamous cell carcinoma of the pancreas. Gastroenterol Hepatol. 2009;32(10):693-6.

10. Nikfam S, Sotoudehmanesh R, Pourshams A, Sadeghipour A, Sotoudeh M, Mohamadnejad M. Squamous cell carcinoma of the pancreas. Arch Iran Med. 2013;16(6):369-70.

11. Brijbassie A, Stelow E, Shami VM. Squamous cell carcinoma of the pancreas: a case report and review of literature. Gastroenterol Res. 2014;7(3-4):102-4. 
12. Mehta M, Sinha J, Ogawa M, Ganguly A, Xiang D, Poddar N. Unusual case of squamous cell carcinoma of pancreas with review of literature. J Gastrointest Cancer. 2015;46(4):426-9.

13. Rowe K, Mehta J, Nehme F, Salyers W. Primary squamous cell carcinoma of the pancreas as a cause of biliary obstruction. Cureus. 2016;8(10):e856.

14. Modi RM, Kamboj AK, Shen R, Krishna SG. Endosonography and confocal endomicroscopy of primary keratinizing squamous cell carcinoma of the pancreas. ACG Case Rep J. 2017;4:e 17.

15. Martinez de Juan F, Reolid Escribano M, Martinez Lapiedra C, Maiade Alcantara F, Caballero Soto M, Calatrava Fons A, Machado I. Pancreatic adenosquamous carcinoma and intraductal papillary mucinous neoplasm in a CDKN2A germline mutation carrier. World J Gastrointest Oncol. 2017:9(9):390-6.

16. Kashani A, Kahn M, Jamil LH. Diagnosis of primary squamous cell carcinoma of the pancreas using endoscopic ultrasound-guided core needle biopsy. Gastroenterol Rep. 2015;5(1):72-4.

17. Zhang G, Cheng ZZ, Xu GH, Jiang X, Wang XX, Wang QF. Primary squamous cell carcinoma of the pancreas with effective comprehensive treatment: a case report and literature review. Medicine. 2018;97(41):12253.

18. Alajlan BA, Bernadt CT, Kushnir VM. Primary squamous cell carcinoma of the pancreas: a case report and literature review. J Gastrointest Cancer. 2019;50(1):130-3.

19. Kodavatiganti R, Campbell F, Hashmi A, Gollins SW. Primary squamous cell carcinoma of the pancreas: a case report and review of the literature. J Med Case Rep. 2012;6:295.

20. Glass R, Andrawes SA, Hamele-Bena D, Tong GX. Metastatic tonsillar squamous cell carcinoma masquerading as a pancreatic cystic tumor and diagnosed by EUS-guided FNA. Diagn Cytopathol. 2017;45(11):1042-5.

21. Abedi SH, Ahmadzadeh A, Mohammad Alizadeh AH. Pancreatic squamous cell carcinoma. Case Rep Gastroenterol. 2017;11(1):219-24.
22. De Moura DTH, Coronel M, Chacon DA, Tanigawa R, Chaves DM, Matuguma SE, Dos Santos MEL, Jukemura J, De Moura EGH. Primary adenosquamous cell carcinoma of the pancreas: the use of endoscopic ultrasound guided - fine needle aspiration to establish a definitive cytologic diagnosis. Revista de gastroenterologia del Peru : organo oficial de la Sociedad de Gastroenterologia del Peru. 2017;37(4):370-3.

23. Machairas N, Paspala A, Schizas D, Ntomi V, Moris D, Tsilimigras DI, Misiakos EP, Machairas A. Metastatic squamous cell carcinoma to the pancreas: report of an extremely rare case. Mol Clin Oncol. 2019;10(1):144-6.

24. Minami T, Fukui K, Morita Y, Kondo S, Ohmori Y, Kanayama S, Taenaka $\mathrm{N}$, Yoshikawa K, Tsujimura T. A case of squamous cell carcinoma of the pancreas with an initial symptom of tarry stool. J Gastroenterol Hepatol. 2001;16(9):1077-9.

25. Tella SH, Kommalapati A, Yadav S, Bergquist JR, Truty MJ, Durgin L, Ma WW, Cleary SP, McWilliams RR, Mahipal A. Survival and prognostic factors in patients with pancreatic squamous cell carcinoma. Eur J Surg Oncol. 2019;45(9):1700-5.

26. Lin E, Veeramachaneni $H$, Addissie B, Arora A. Squamous cell carcinoma of the pancreas. Am J Med Sci. 2018;355(1):94-6.

27. Pancreas ESGoCTot: European evidence-based guidelines on pancreatic cystic neoplasms. Gut 2018, 67(5):789-804.

28. European Study Group on Cystic Tumours of the P. European evidence-based guidelines on pancreatic cystic neoplasms. Gut 2018, 67(5):789-804.

\section{Publisher's Note}

Springer Nature remains neutral with regard to jurisdictional claims in published maps and institutional affiliations.
Ready to submit your research? Choose BMC and benefit from:

- fast, convenient online submission

- thorough peer review by experienced researchers in your field

- rapid publication on acceptance

- support for research data, including large and complex data types

- gold Open Access which fosters wider collaboration and increased citations

- maximum visibility for your research: over 100M website views per year

At BMC, research is always in progress.

Learn more biomedcentral.com/submissions 